\title{
BACTERIAL DNA EXTRACTION METHOD FOR THE DETECTION OF HELICOBACTER PYLORI FROM HUMAN FECAL SAMPLES
}

\author{
JHOAN GUAMÁN ${ }^{1}$, FAVIAN BAYAS-MOREJÓN ${ }^{1 *}$, ELENA BRITO² ${ }^{2}$ NORMA PAREDES $^{3}$
}

${ }^{1}$ Department of Research, Center for Biotechnological Research and Development, Faculty of Agricultural Sciences Natural and Environmental Resources, Bolivar State University, Guaranda, Ecuador. ${ }^{2}$ Clinical Laboratory Degree, Faculty of Health Sciences, National University of Chimborazo, Riobamba, Riobamba, Ecuador. ${ }^{3}$ Nursing Degree, Faculty of Health and Human Sciences, Bolivar State University, CP: 020150, Guaranda-Ecuador. Email: fbayas@ueb.edu.ec

Received: 05 March 2020, Revised and Accepted: 16 April 2020

\section{ABSTRACT}

Objective: The work proposed the implementation of a method of DNA extraction for the detection of the pathogen from 50 stool samples.

Methods: A method of DNA extraction with Chelex resin was applied and then detected by conventional polymerase chain reaction (PCR).

Results: By PCR, 11 samples were positive for Helicobacter pylori.

Conclusions: The Chelex extraction methodology allows obtaining DNA with quality necessary to be detected by PCR, making it a fast methodology for its diagnostic application

Keywords: DNA extraction, Helicobacter pylori, Polymerase chain reaction, Gastritis.

(C) 2020 The Authors. Published by Innovare Academic Sciences Pvt Ltd. This is an open access article under the CC BY license (http://creativecommons. org/licenses/by/4. 0/) DOI: http://dx.doi.org/10.22159/ajpcr.2020.v13i6.37344

\section{INTRODUCTION}

Helicobacterpyloriis amicroorganismbelongingto theHelicobacteraceae family, order of the Campylobacterales, this microorganism is able to colonize the gastric mucosa of human beings naturally. Moreover, this bacterium is considered a pathogen of global interest because it is a very easy contagion microorganism between hosts or hosts [1]. H. pylori infection is now recognized as a problem that causes chronic gastritis, peptic ulcer disease, and lymphoproliferative disorders and is a major risk factor for gastric cancer [2].

Diagnostic methods to detect H. pylori are classified as direct or invasive; the directly identify is when the bacteria are obtained by biopsy of the gastric mucosa by histology endoscopy with various staining techniques. However, stool culture techniques and polymerase chain reaction (PCR) are non-invasive methods or serological tests such as the urea breath test marked with $13 \mathrm{C}$ (techniques least harmful for the patient) $[3,4]$.

Each of these techniques or detection methods used has its advantages and disadvantages in its operation, they are not perfect, but they have been improving in the last decade, especially molecular techniques. In the same way, the search for alternatives such as the use of resins and new detergents facilitates the processes of extraction of genetic material, among these aspects, it stands out that Chelex is a cheating resin available as an analytical grade, this analytical resin has been dimensioned, extensively purified, and converted to be an accurate and reproducible analytical technique; something to highlight about this technique is that it does not require a previous digestion with enzymes such as proteinase $\mathrm{K}$ [5-7].

Considering the previously described, the objective of this work was to evaluate the application of a bacterial DNA extraction method for the detection of $H$. pylori in human fecal samples by conventional PCR.

\section{METHODS}

\section{Selection and sampling}

The research included a total of 50 patient samples, 34 (68\%) women and $16(32 \%)$ men, these samples were selected, from a clinical record for medical importance. The experimental study was carried out in the molecular biology laboratory, belonging to the Research Department of the Universidad Estatal de Bolívar (Guaranda, Ecuador).

\section{Bacterial DNA extraction}

With the samples obtained from patients who presented with gastric problems or associated symptoms, bacterial DNA was extracted using the Chelex method [8]. For which, the strains of $H$. pylori (Hp17C2 and Hp34C1) previously confirmed by microscopy were used as controls. To identify the presence of the DNA obtained, a combination of factors was applied by the experimental design, as shown in Table 1.

\section{Description of the method of DNA extraction with Chelex resin}

The technique was carried out as follows:

- A bacterial culture (60.3 mg of biomass) is suspended in $300 \mu \mathrm{L}$ of 1X TAE buffer (Invitrogen, 24710-030, USA).

- The resuspension was centrifuged at $13,000 \times \mathrm{g}$ for $15 \mathrm{~min}$ at $4^{\circ} \mathrm{C}$. The pellet was washed 3 times by suspending it in $1.5 \mathrm{~mL}$ of acetone. Each preparation was centrifuged at 13,000 $\mathrm{xg}$ for $10 \mathrm{~min}$ at $4^{\circ} \mathrm{C}$.

- The supernatant was removed and the pellet was retained for later analysis.

- About $200 \mu \mathrm{L}$ of Chelex-100 resin (5\%) and $0.2 \mathrm{mg}$ of proteinase $\mathrm{K}$ were added to the pellets and then incubated considering the experimental design parameters (Table 1 ).

- Each of the preparations was homogenized and subsequently centrifuged at $100,000 \times g$ for $5 \mathrm{~min}$. Finally, $100 \mu \mathrm{L}$ of the supernatant was transferred to sterile tubes for further analysis.

To confirm the presence of the DNA obtained, an analysis was performed by $0.8 \%$ agarose gel electrophoresis in $1 \times$ TAE buffer, with the addition of $10 \mu \mathrm{L}$ of RedSafe, it was exposed to 100 volts for $30 \mathrm{~min}$. A volume of $10 \mu \mathrm{L}$ of DNA previously mixed with $2 \mu \mathrm{L}$ of loading buffer (Promega, G190A, USA) was used. A 50 bp molecular weight marker was included. Finally, the fragments were visualized in a UV transilluminator (Dark Reader, DR-46B, USA) 
Table 1: Combination of factors for DNA extraction using the Chelex method

\begin{tabular}{ll}
\hline Treatments & Description \\
\hline $\mathrm{A}_{1} \mathrm{~B}_{1}(\mathrm{~T} 1)$ & Incubated at $56^{\circ} \mathrm{C}$ for $20 \mathrm{~min}$ \\
$\mathrm{~A}_{1} \mathrm{~B}_{2}$ (T2) & Incubated at $56^{\circ} \mathrm{C}$ for $30 \mathrm{~min}$ \\
$\mathrm{~A}_{1} \mathrm{~B}_{3}$ (T3) & Incubated at $56^{\circ} \mathrm{C}$ for $40 \mathrm{~min}$ \\
$\mathrm{~A}_{2} \mathrm{~B}_{1}$ (T4) & Incubated at $75^{\circ} \mathrm{C}$ for $20 \mathrm{~min}$ \\
$\mathrm{~A}_{2} \mathrm{~B}_{2}$ (T5) & Incubated at $75^{\circ} \mathrm{C}$ for $30 \mathrm{~min}$ \\
$\mathrm{~A}_{2} \mathrm{~B}_{3}$ (T6) & Incubated at $75^{\circ} \mathrm{C}$ for $40 \mathrm{~min}$ \\
\hline
\end{tabular}

Where factor $\mathrm{A}$ corresponds to incubation temperature and factor $\mathrm{B}$ corresponded to incubation time

Table 2: Tukey test of DNA extraction treatments

\begin{tabular}{lll}
\hline Treatment number & Treatments & Pureza (A260/A280) \\
\hline 5 & $\mathrm{~A}_{2} \mathrm{~B}_{2}$ & $1.88 \mathrm{a}$ \\
6 & $\mathrm{~A}_{2} \mathrm{~B}_{3}$ & $1.66 \mathrm{~b}$ \\
3 & $\mathrm{~A}_{1} \mathrm{~B}_{3}$ & $1.64 \mathrm{bc}$ \\
4 & $\mathrm{~A}_{2} \mathrm{~B}_{1}$ & $1.62 \mathrm{c}$ \\
2 & $\mathrm{~A}_{1} \mathrm{~B}_{2}$ & $1.18 \mathrm{~d}$ \\
1 & $\mathrm{~A}_{1} \mathrm{~B}_{1}$ & $0.95 \mathrm{e}$ \\
\hline
\end{tabular}

Means with a common letter are not significantly different $(p>0.05)$

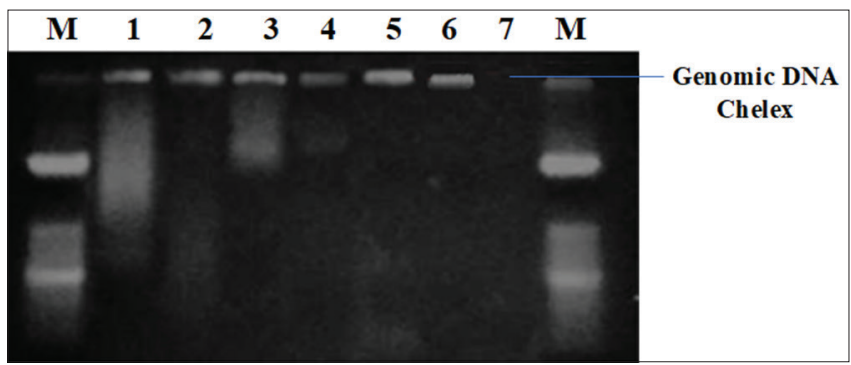

Fig. 1: Analysis of electrophoresis of DNA extracted by the Chelex method in isolate Hp17C2. Lanes M: 50-bp Ladder; Lane1, 2, 3, 4, 5 and 6: treatments 1, 2, 3, 4, 5 and 6 respectively; lane 7: negative control

\section{Molecular analysis}

The molecular analysis was performed using the PCR technique that amplifies a 394 bp fragment. Therefore, the initiators, reagents, and conditions described by Santiago et al. [9] were used.

\section{RESULTS AND DISCUSSION}

Of the 32 isolates under study, 2 of them as controls (Hp17C2 and Hp34C1) were selected for their plate viability for subsequent DNA extraction using the Chelex method.

After Chelex extraction, the DNA obtained showed a higher quality without contamination or inhibitors [10]. Employing the statistical analysis, it can be considered that there is a significant statistical difference between the treatments, where the treatment $5=\mathrm{A}_{2} \mathrm{~B}_{2}$ (incubated at $75^{\circ} \mathrm{C}$ for $30 \mathrm{~min}$ ) was the one that presented a higher absorbance level of $1.88 \mathrm{~nm}$ of $\lambda$ purity, as shown in Table 2 , this result proved to be within what was established to be considered the DNA of optimum quality (1.8-2 $\mathrm{nm}$ ) according to the Carlos III National DNA Bank of the University of Salamanca [11].

Similar results to ours were obtained by Ahmed et al. [12], after comparing different DNA extraction methods, concluded that the Chelex 100-Microwave method was the best with an average DNA concentration of $80.1 \mu \mathrm{g} / \mathrm{mL}(\mathrm{A} 260 / 280,1.82)$ for Staphylococcus aureus. In the same way, Devi et al. [13], with a DNA purity of A260/280: 1.76, used Chelex resin to extract the genetic material of environmental bacteria from the soil. On the other hand, it is important to emphasize that there is

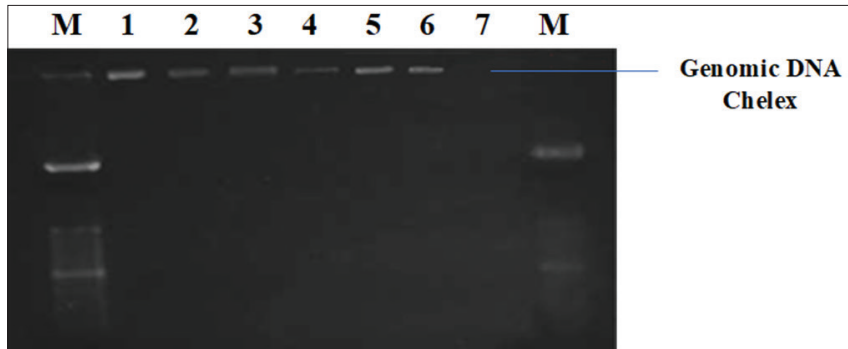

Fig. 2: Electrophoresis analysis of DNA extracted using the Chelex method in isolate Hp34C1. Lanes M: 50-bp Ladder; Lane1, 2, 3, 4, 5 and 6: treatments 1, 2, 3, 4, 5 and 6 respectively; lane 7: negative control

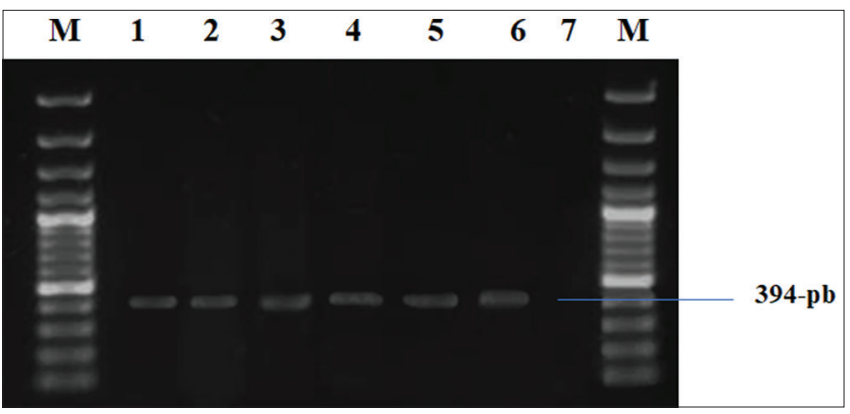

Fig. 3: Analysis of PCR amplified electrophoresis of the amplified DNA and extracted by the Chelex method (Treatment 5 "A2B2") in the isolates obtained. Lanes M: 100-bp ladder; lanes 1-6: positive isolates; lane 7: negative control

only one work carried out by García-Cuan and Miranda [14] who used the Chelex resin with modifications to extract $H$. pylori DNA, the purity of the DNA was A260/A280 of 1.6, however, this value is less to that obtained in the best treatment of our study.

Likewise, DNA quality was analyzed by agarose gel electrophoresis, high DNA quality was evident in all treatments, although with greater fluorescence in treatments $1,3,5$, and 6 ; this is due to low concentration of DNA target [15] so that the isolate was continued with PCR amplification. The DNA quality of isolated controls is evidenced in Fig. 1: Hp17C2 and Fig. 2: Hp34C1.

In summary, considering that absorbance and transillumination by electrophoresis, the best DNA obtained was from the 5 " $\mathrm{A}_{2} \mathrm{~B}_{2}$ " treatment (incubated at $75^{\circ} \mathrm{C}$ for $30 \mathrm{~min}$ ). It can be considered that time and temperatures did have a significant influence on obtaining the DNA. Furthermore, that treatment 5 was the best after electrophoretic and statistical analysis of comparison of means according to Tukey, using this best treatment, the PCR amplification was carried out. Next PCR analysis with the specific initiators for H. pylori VacAF and VacAR [9], 11 samples were positive 7 of women and 4 of men. From the isolates of these samples, the characteristic band of $394 \mathrm{pb}$ was obtained, as shown in Fig. 3.

\section{CONCLUSIONS}

The Chelex extraction methodology allows obtaining DNA with the quality necessary to be detected by PCR, making it a fast methodology for its diagnostic application for H. pylori.

\section{ACKNOWLEDGMENT}

The authors express their full gratitude to the State of Bolivar University and to the debt exchange program Ecuador-Spain, for the support received in carrying out the present work. 


\section{AUTHORS' CONTRIBUTIONS}

The author declares that this work was done by the author named in this article.

\section{CONFLICTS OF INTEREST}

We declare that we have no conflicts of interest.

\section{AUTHORS' FUNDING}

This work was financed by the Ecuador-Spain debt swap program through the project: K007_271218.

\section{REFERENCES}

1. Frías Ordoñez J, Otero W. Practical issues in diagnostic tests for Helicobacter pylori infection: A narrative review. Rev Gastroenterol Peru 2017;37:246-53.

2. Bayas-Morejón IF, Tigre-León RA, Ramón-Curay R, Núñez-Torres D. Helicobacter pylori: A pathogen of ample risk to health. In: Roesler BM, editor. Gastritis-new Approaches and Treatments. UK: IntechOpen; 2019. p. 1-13.

3. Rafeey M, Nikvash S. Detection of Helicobacter pylori antigen in stool samples for diagnosis of infection in children. East Mediterr Health J 2007;13:1067-72.

4. Morejón FB. Aportaciones a la Epidemiología de Arcobacter y Helicobacter Aplicación de Métodos Moleculares a su Detección e Identificación en Alimentos [Tesis Doctoral]. Valencia: Universidad Politécnica de Valencia; 2016.

5. Moreno Y, Piqueres P, Alonso JL, Jiménez A, González A, Ferrús MA.
Survival and viability of Helicobacter pylori after inoculation into chlorinated drinking water. Water Res 2007;41:3490-96

6. Nobel HA. Bio-Rad Laboratories; 2017. Available from: http://www. biorad.com/webmaster/pdfs/9184 chelex.pdf.

7. Tigre A, Erazo F, Yánez D, Bayas-Morejón F. Phylogenetic analysis of Fusarium oxysporum $\mathrm{F}$ strains isolated from strawberry crops Fragaria ananassa Duch in the province of Pichincha (Ecuador). Int J Curr Pharm Res 2020;12:92-5.

8. Suenaga E, Nakamura H. Evaluation of three methods for effective extraction of DNA from human hair. J Chromatogr B Analyt Technol Biomed Life Sci 2005;820:137-41.

9. Santiago P, Moreno Y, Ferrús MA. Identification of viable Helicobacter pylori in drinking water supplies by cultural and molecular techniques. Helicobacter 2015;20:252-9.

10. Butler JM. DNA Extraction from Forensic Samples Using Chelex. New York: CSHL Press; 2007. p. 1.

11. Universidad de Salamanca. Banco Nacional de ADN Carlos III. Spain: Universidad de Salamanca, BancoAdn; 2004. p. 1.

12. Ahmed O, Asghar AH, Elhassan M. Comparison of three DNA extraction methods for polymerase chain reaction (PCR) analysis of bacterial genomic DNA. Afr J Microbiol Res 2014;8:598-602.

13. Devi SG, Fathima AA, Radha S, Arunraj R, Curtis WR, Ramya M. A rapid and economical method for efficient DNA extraction from diverse soils suitable for metagenomic applications. PLoS One 2015; $10: \mathrm{e} 0132441$

14. García-Cuan A, Miranda A. Evaluation of bacterial DNA extraction methods in fecal samples of patients diagnosed with Helicobacter pylori infection. Biociencias 2018;13:6-7.

15. Widada H, Rohman A, Jenie R, Sismindari S. Application of graphene oxide on aptamer-based biosensor development for authentication of gelatin. Int J Appl Pharm 2019;11:254-8. 